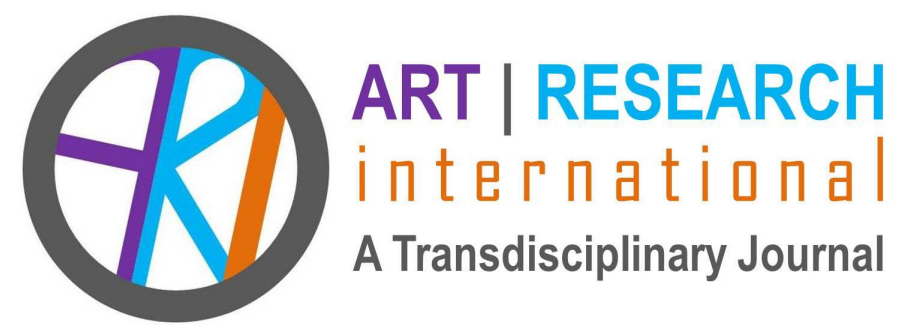

\title{
MAKING SENSE OF A CHANGING NEIGHBORHOOD: ART STUDENTS' EXPERIENCES OF PLACE EXPLORED THROUGH A MATERIAL-DISCURSIVE ANALYTICAL LENS
}

\author{
Sara Coemans \\ University of Leuven \\ sara.coemans@kuleuven.be \\ Joke Vandenabeele \\ University of Leuven \\ joke.vandenabeele@kuleuven.be
}

Karin Hannes

University of Leuven karin.hannes@kuleuven.be

Sara Coemans is a $\mathrm{PhD}$ researcher at the Laboratory for Education and Society (Faculty of Psychology and Educational Sciences) of the University of Leuven. In her research, she explores the potential of arts-based and multi-sensory approaches to study the relationship between people and their surroundings.

Joke Vandenabeele is associate professor at the Faculty of Psychology and Educational Sciences (and part of the Laboratory for Education and Society) of the University of Leuven. She has developed her educational research in relation to two important social issues: the issue of solidarity and the issue of sustainability. She uses an action research approach to foster, both empirically and theoretically, a reflection on how community education emerges from what people actually do together and also how the materiality of a particular practice is part of this specific togetherness. 
Karin Hannes is associate professor at the Faculty of Social Sciences (Social Research Methodology Group) of the University of Leuven. Her main research interest is in developing, applying, and refining approaches to qualitative research. She is most known for her academic contributions in the area of qualitative evidence synthesis. On a primary research level, she has been focusing on the use and further development of arts-based, multi-sensory, and place-based research methods in the context of public health, social-cultural and social welfare practice.

Abstract: Sensory research approaches are often used to study the relationship between people and their living environment. The type of data collected in such research projects poses analytical challenges. How do we best make sense of a body of visual, auditory, tactile data? How do such data contribute to our knowing? In this paper, we propose and illustrate an analytical apparatus for studying the complex entanglement of discursive and material aspects of sensorial experiences related to place. Place-interactive methods such as sensory go-along interviews with art students and voice-giving procedures through the making of art works formed the basis for the analysis.

Keywords: arts-based research; sensory methodology; place; go-along interviews; material-discursive analysis 
How can a sensory research approach bring into account the material dimension of a changing neighborhood? In the past four years, we explored the potential of such an approach in a number of small research experiments conducted in a Belgian urban renewal setting. We involved different groups of participants, including a group of adult residents living in the urban area, a group of youngsters following a school alternative programme in the neighborhood, and a group of art students studying at the nearby art academy. In this paper, we focus on an experiment in which we engaged this last group, four art students, in sensory walks through the neighborhood and in the process of making various art works (including sketches, paintings, photographs, and installations) based upon these walks.

The experiment was grounded in the research tradition of sensory ethnography. The academic interest in this ethnographical approach has been growing in recent years, as is the interest in visual, auditory, tactile, gustative, olfactory, and other sensorial dimensions of experience (Hurdley \& Dicks, 2011). This is

based on the understanding that human meaning does not emerge only from [verbal] language; it engages with the ways in which our sensory experience is pre-or non-linguistic, and part of our bodily being in the world. (Karel, 2013, p. $\mathrm{x})$

Sensory ethnography takes a critical stance towards research in which a dialogue with participants is detached from the place under study (Anderson, Adey, \& Bevan, 2010, p. 589). Instead, it reconceptualizes the interview as a "place-event"; "a process through which verbal, experiential, emotional, sensory, material, social and other encounters are brought together" (Pink, 2009, p. 95). The methodology implies the use of mobile, embodied, place-interactive research practices, for instance walking with participants while conducting interviews (e.g. Anderson, 2004; Carpiano, 2009; Kusenbach, 2003; Pink, 2007; Pink, Hubbard, O'Neill, \& Radley, 2010). While traditional forms of interviewing can provide "information on abstract orientations to place through information on participants' thoughts, memories, and feelings as they relate to place" (Tuck \& McKenzie, 2015, p. 99), "go-along" or walking interviews (Evans \& Jones, 2012) allow researchers and participants to consider physical aspects of the place as well as how elements that can be seen, touched, heard, or smelled trigger new thoughts and experiences that affect understandings and actions (Tuck \& McKenzie, 2015). Sensory ethnography also opens up other possibilities than academic writing that go beyond text, focusing on the tacit and non-verbal. This can lead to engagements with arts practice (Pink, 2009). 
While a lot of sensory studies provide their readers with information about the process of conducting sensory ethnography, detailed accounts of analytical procedures that engage with sense data are underrepresented in the literature. As Sarah Pink (2009) ascertains, analyzing "experiential, imaginative, sensorial and emotional dimensions of ethnography is itself often an intuitive, messy and sometimes serendipitous task" (p. 119). In this paper, we shift our focus from an analysis purely based on written interview transcripts or reflective notes of the researcher, to a more sensory way of analyzing art works made in the context of this study. In doing so, it is our intention to develop an awareness of how a variety of research materials can "facilitate ways of being close to the non-verbal, tacit, emplaced knowledge that a sensory analysis seeks to identify" (Pink, 2009, p. 130).

In our study, sensory research approaches were used to study the relationship between people and their living environment. The objective of this paper is to expose readers to the analytical apparatus we developed to increase our understanding of: (a) how producing art works in the context of a sensory research project can be seen as data; and (b) how art works can contribute to articulating the kind of city its dwellers want.

\section{Theoretical Grounding}

To investigate material, embodied, tacit dimensions of place experiences, we turn to John Dewey's pragmatic aesthetic inquiry (Dewey, 1934; Siegesmund, 2012; Siegesmund, 2017) for guidance. In his book, Art as Experience, Dewey refers to an aesthetic of immediate living within the everyday, which is an engagement with the world around us. This aesthetic "in the raw" (Leddy, 2016) starts from everyday events and scenes in which the interaction between humans and their environment plays a central role. This relation between humans and their environment is essentially organic. The world is not waiting there passively to be discovered by humans. It is through our human and material interactions that we experience and create our world (Siegesmund \& Freedman, 2018). Through our direct experiences of the world, we absorb the aesthetic features of nature and recognize its qualities. As Johnson (2007) describes:

"I know my world by the distinctive light, warmth, and fragrant breeze of a spring day, just as much as I know it by the driving rain, cold winds, and pervading darkness of a stormy winter afternoon. I know you by the qualities of your distinctive eyes, your mouth, your voice, your smell, the character of your walk, and how you hold yourself. All of my thinking emerges within this qualitative world, to which it must return if it is to have any connection with my life." (p. 69) 
These qualities of experience can be sensed, heard, smelled, and felt and they constitute our world. This sensory way of thinking is what Dewey calls a thinking in the relationships of qualities. Later on, the idea has been further conceptualized by Eisner (1972), one of the founders of arts-based research, as "qualitative reasoning." Eisner contrasted the notion of discursive intelligence (linked to language and symbolic systems) with qualitative intelligence (or non-discursive intelligence, thinking not limited to verbal operations). According to Dewey and Eisner, all experience and thought are based on pervasive qualities. In this way, both scholars critiqued our notion of thinking as being exclusively symbolic in nature (Siegesmund, 2017). Rejecting dualisms between doing and thinking, reflecting and acting, knowing and being, opens up a horizon of creativity in which the world is experienced by doing and undergoing (Baldacchino, 2014).

Works of art can be examples of an experience that entails sensory awareness, a doing and undergoing, and in which different elements

This line of thought served as the starting point for our urban walks are merged into a unity; a pervasive quality.

with students from the art academy. It also assisted us as an interesting analytical pathway for the art works made in the subsequent phase of the research process. Following Dewey, the process of developing these art works can be seen as the "process of making something out of physical material that can be perceived by one of the senses" (Leddy, 2016, p. X). Works of art can be examples of an experience that entails sensory awareness, a doing and undergoing, and in which different elements are merged into a unity; a pervasive quality. In what follows, we introduce the research setting and outline the research process leading to the development of the material-discursive analytical apparatus.

\section{The Canal Bowl}

Our research experiment was set up in the Canal Bowl area, a former industrial site of about 30 hectares in the north of the Belgian city of Leuven, that is undergoing significant transformations. For centuries the area could be seen as the economic heart of the city. The area was put into service in the 18th century for transport activities and small relating industries, housing several beer breweries, salt works, storage facilities, mills, and carpenter sites and, unlike now, only very few residential places. Halfway into the 19th century the building of railroad tracks began in close vicinity of the Canal Bowl, connecting the port to other cities in Belgium. During the second World War most of the buildings were destroyed and the area was renovated (Missotten \& Desmet, 2010). 


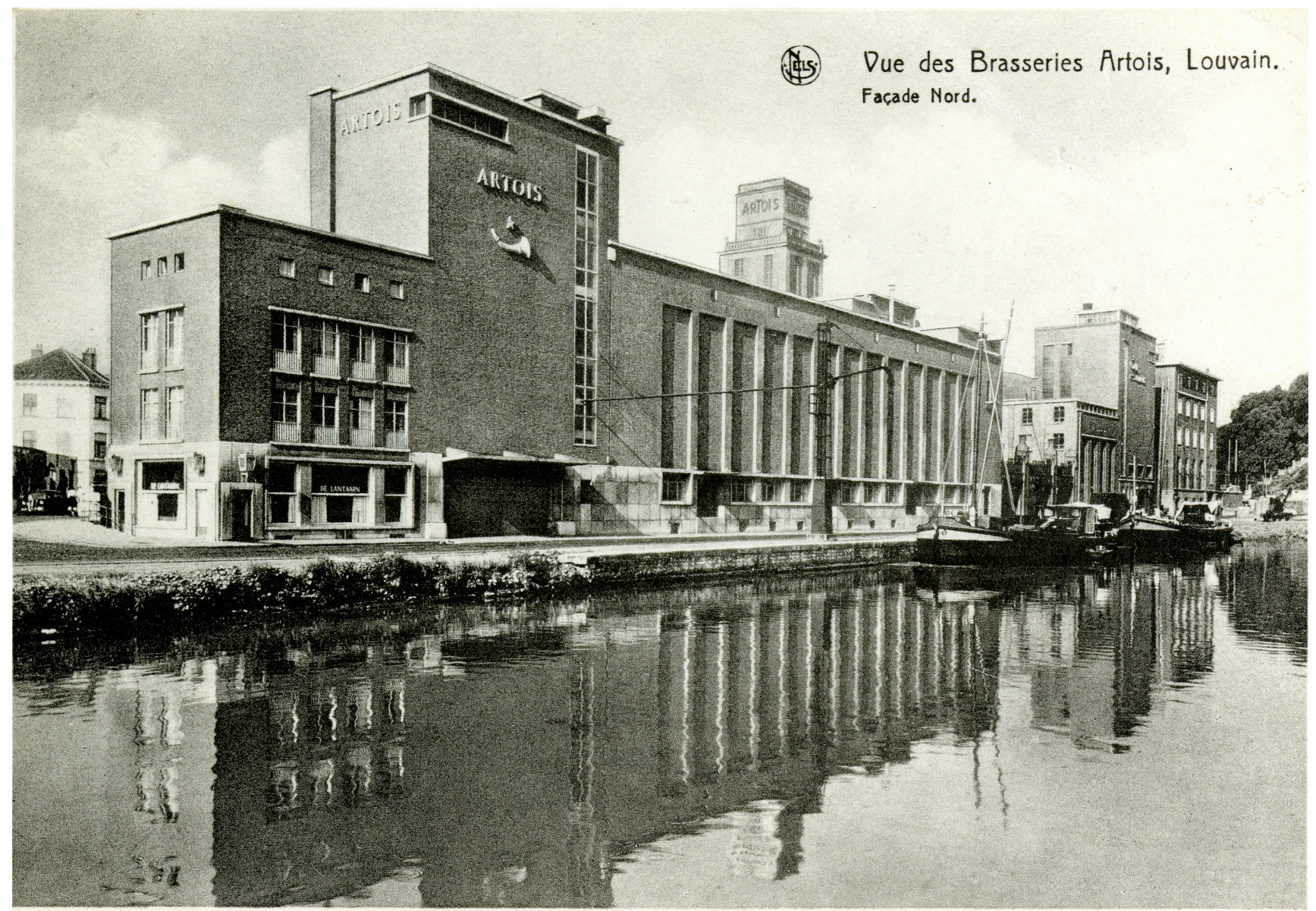

Figure 1. The old industrial site. Photograph courtesy of Stadsarchief Leuven (SAL).

Because of its shallow waterways, competition of road transport, and changing economic activities, the area went into decline. In 2008, the city proposed plans to transform the area into a fully renovated urban district. Since then, everyday life in this area has been characterized by on-going building work. A combination of private homes, social rental and owner-occupied homes, starter, and student homes has currently been built to create a new vibrant, sustainable, environment by the water. What used to be an abandoned part of the city is now turning into a creative and cultural hub "where designers, starters, artists, production companies, cultural associations and craftsmen have a place to stay in affordable spaces ...." (website city of Leuven, https:// www.leuven.be/vaartkom). It has the mission to "create" an urban neighborhood or community by connecting different people within one particular area, an idea that has received much attention under the impulse of the "micro-urbanism" movement promoting "the design and development of small-scale, distinctive neighborhoods and settlements, recreating a small version of a city" (Mandanipour, 2001, p. 172). 


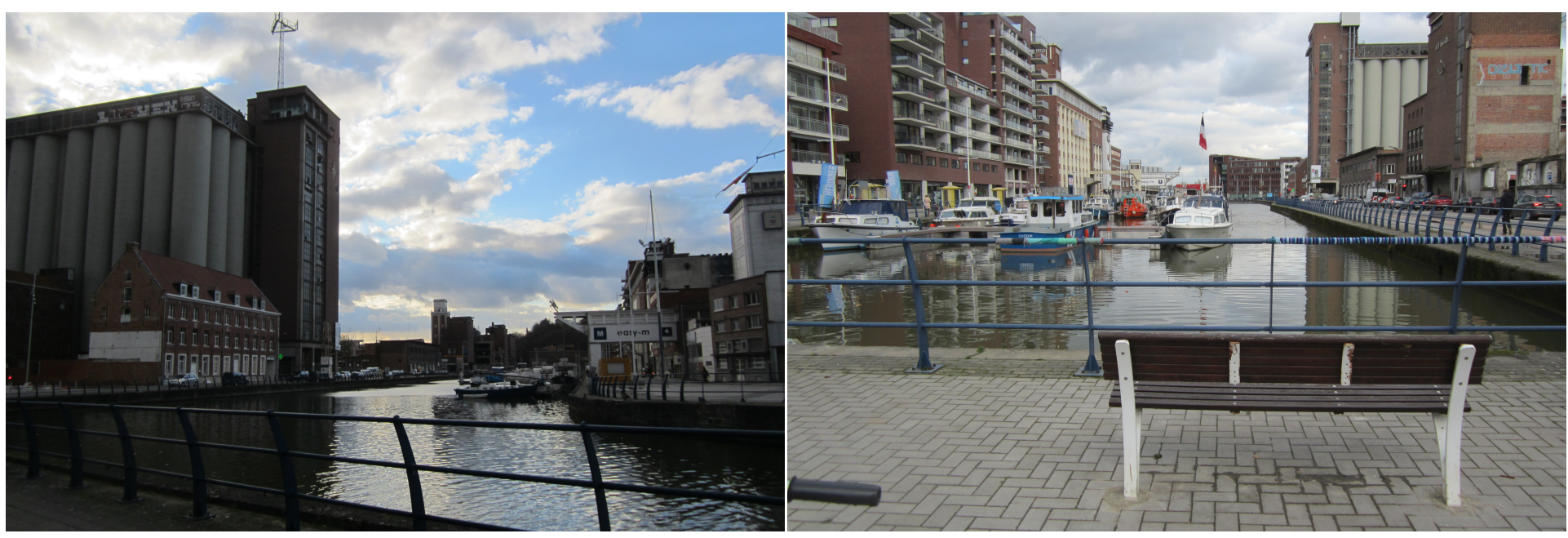

Figure 2. Canal Bowl anno 2017. Photographs courtesy of Tamara Lodder.

\section{The Research Process}

\section{The Sample}

We investigated the experiences of four semi-professional artists studying at the Interdisciplinary Studio of SLAC (the art academy and music conservatory of the city of Leuven). Working with art students created an opportunity to explore the potential of communicating place experiences via an artistic creation, which in turn challenged us to develop an analytical lens that is material-discursive in nature.

For the purpose of this paper we illustrate our analytical endeavor on the basis of the sensory walks and art works of two of the participating students: Monik and Christiane. Monik combines different types of media in her artistic work, under which painting, engraving, and video. She mainly draws inspiration from personal experiences in the context of processes of urbanization. She is part of a committee of local residents studying the consequences of urbanization for their neighborhood and its residents. Christiane has enjoyed seven years of painting lessons from many different teachers, making her a versatile painter with broad knowledge of her craft. More recently, she has broadened her repertoire to installations in combination with photography. She draws inspiration for her artistic work from self-recorded photographs of ordinary situations and from media or photos from the past that evoke memories.

\section{Outline of the Study}

We used a five-stage research approach that consisted of the following steps: setting up the collaborative project, walking, creating, disseminating, and analyzing. 
Stage 1: Setting up a collaboration. The research experiment was part of a broader collaborative project between the University of Leuven and the fine arts department of SLAC. The project, that was named PiLoT1, was launched in the academic year 2016-2017 and was part of the University's cultural policy plans. Researchers from several academic disciplines (including educational sciences, sociology, psychology, philosophy, criminology, neurosciences, biomedical sciences, physics, astronomy, and engineering) and advanced students from SLAC worked together on themes in which art and research could encounter one another and could be mutually enriching. The ultimate goal of this cooperation was not only the creation of a work of art but also the "navigating, experimenting, testing and bridging of the two worlds" (Catalogue PiLoT1). In October 2016, we presented our research plan on placebased research and multisensory methods during a first meeting with researchers from the university and art students from SLAC. Four students decided to work with us.

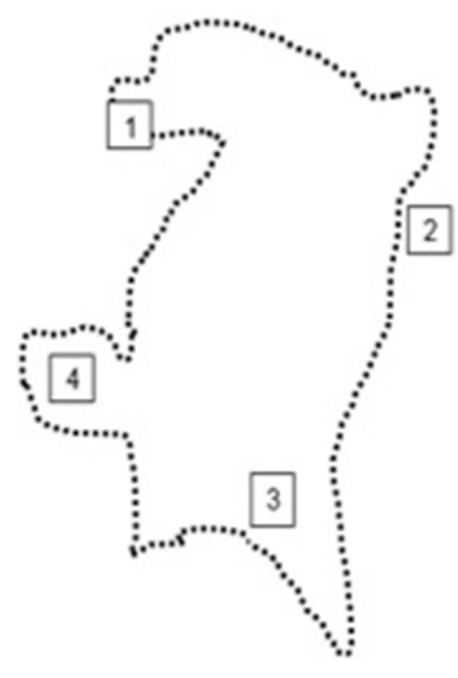

1

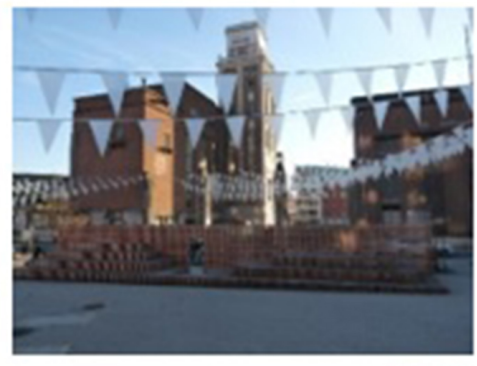

3

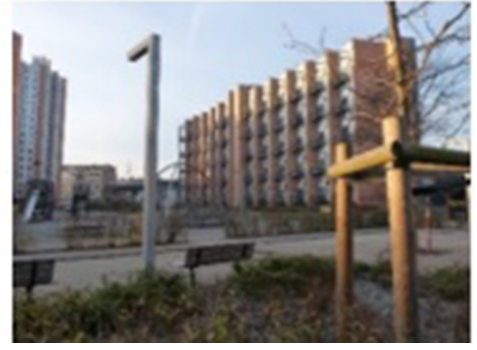

2

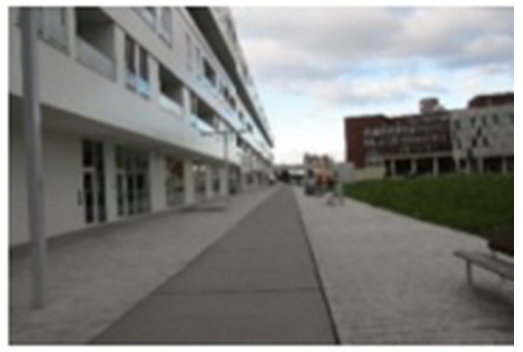

4

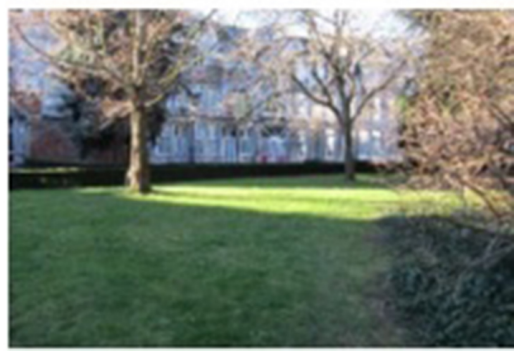

Figure 3. The go-along route with some anchor points. Photographs courtesy of Tamara Lodder and Caroline Van den Nieuwenhuizen.

Stage 2: Walking-connecting. As a hybrid form between participant observation and interviewing (Kusenbach, 2003) sensory go-along interviews were held with the art students to explore the changing Canal Bowl area. During these individual semistructured interviews, we walked, talked and experienced the urban environment together (see Figure 3). The walking exercises encouraged sensory awareness and active attention to what was going on. The walks did not isolate a particular sense but tuned into the students' multi-sensuous experiences. Attention was given to the material and atmospheric environment by sensory prompting; asking what the art students in situ 
saw, felt, touched, heard, smelled, etc. The journeys were audio recorded and transcribed afterward.

As Wylie (2005, as cited in O'Neill \& Hubbard, 2010) pointed out, these kind of walking exercises allowed the participants to reflect on the more-than-rational: the "shifting mood, tenor, colour or intensity of places and situations" (p. 236). Such phenomenologies of place are rather difficult to represent "without lapsing into the languages and practices of sedentary and rational social science (O'Neill \& Hubbard, 2010 , p. 47). Therefore, we might need a language "closer to the multidimensionality of the subject itself, that is a language operating in visual, aural, verbal, temporal and even tactile domains" (Mc Dougal, 2005, p. 116, as cited in Pink, 2009). This search for a more embodied spatial practice led us to the making of art works in the context of the research project.

Stage 3: Creating-responding. The third stage of this study was highly informed by the tradition of arts-based research, which can be seen as a transdisciplinary approach, situated at the intersection of the arts and social science research (Chilton \& Leavy, 2014). More specifically, our way of working can be categorized as a hybrid between "art as research" - which refers to an approach in which research facilitates the study of the artistic process - and "art in research" - where art is actively applied by research participants as a creative process in one or more phases of a research process studying social phenomena (Wang, Coemans, Siegesmund, \& Hannes, 2017). In the context of this study, art students were invited to make a work of art based upon their experiences of the walk, in close collaboration with the researchers. Art students were involved as co-researchers in the process, whereby the act of creating was simultaneously the act of researching the urban renewal area (Wang, Coemans, Siegesmund, \& Hannes, 2017). Art students and researchers gathered multiple times to discuss sensory scholarship, to talk about their walking experiences, and to share interview transcripts, preliminary sketches, and images (see Figure 4).

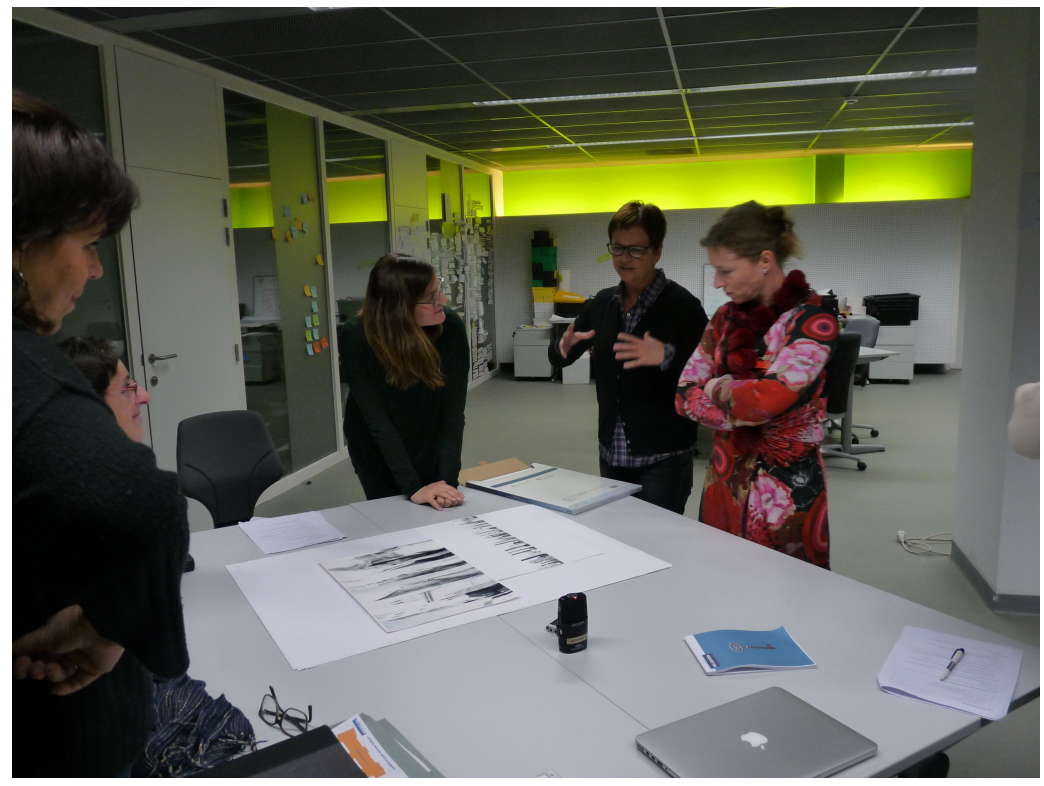

Figure 4. Collaborative process. 


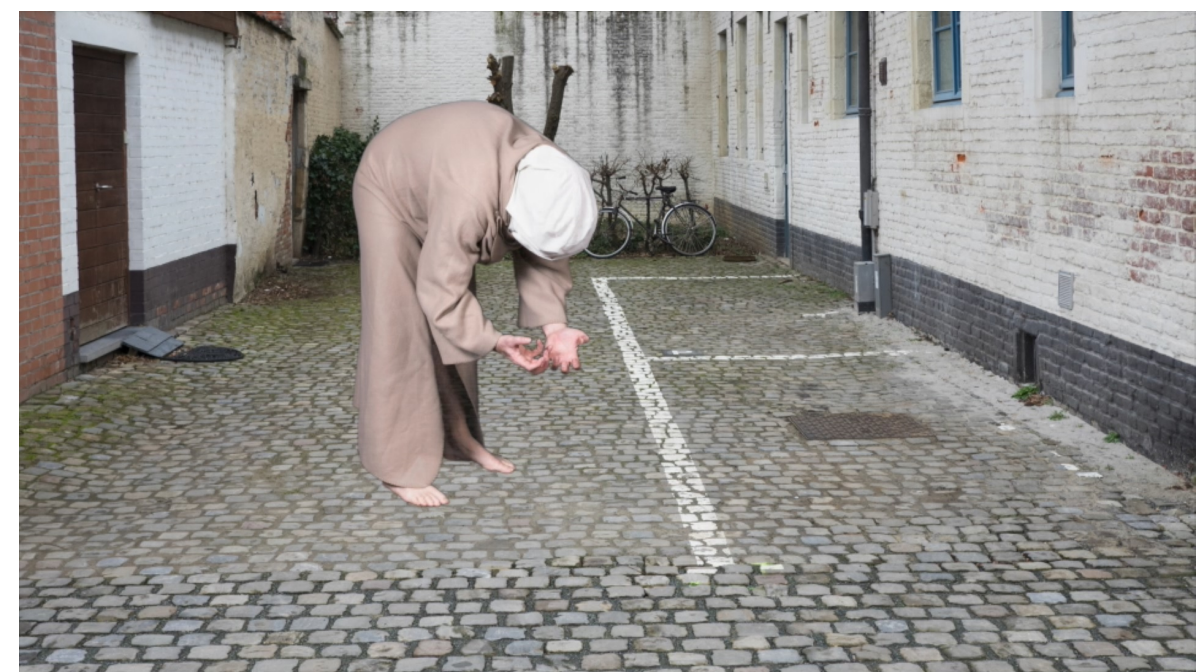

Still shot of video, Patrick De Nys

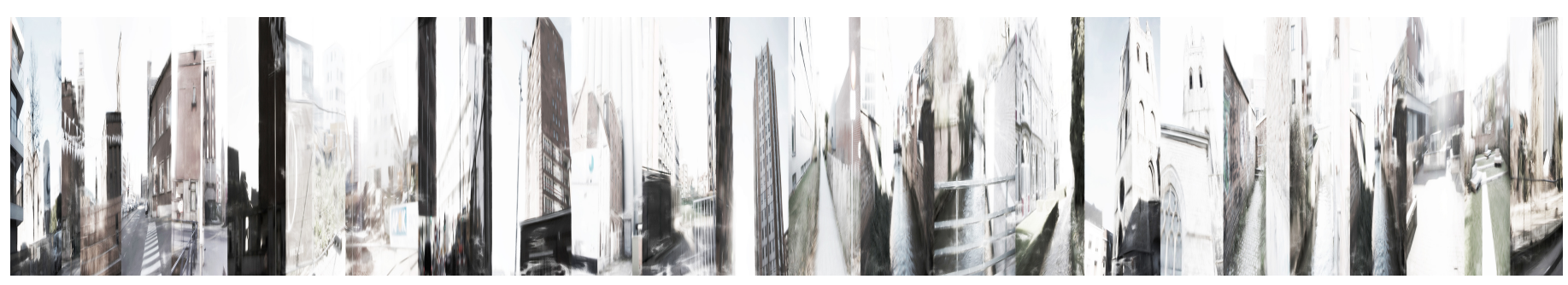

Photo collage, Annemie Moriau

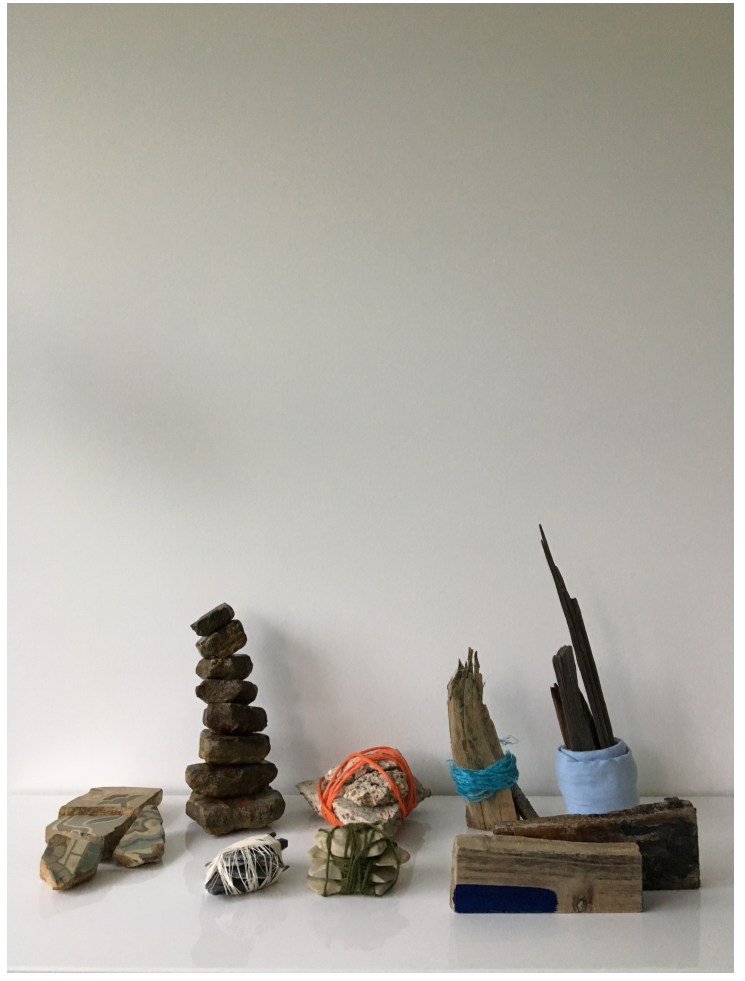

Installation, Christiane Aerts

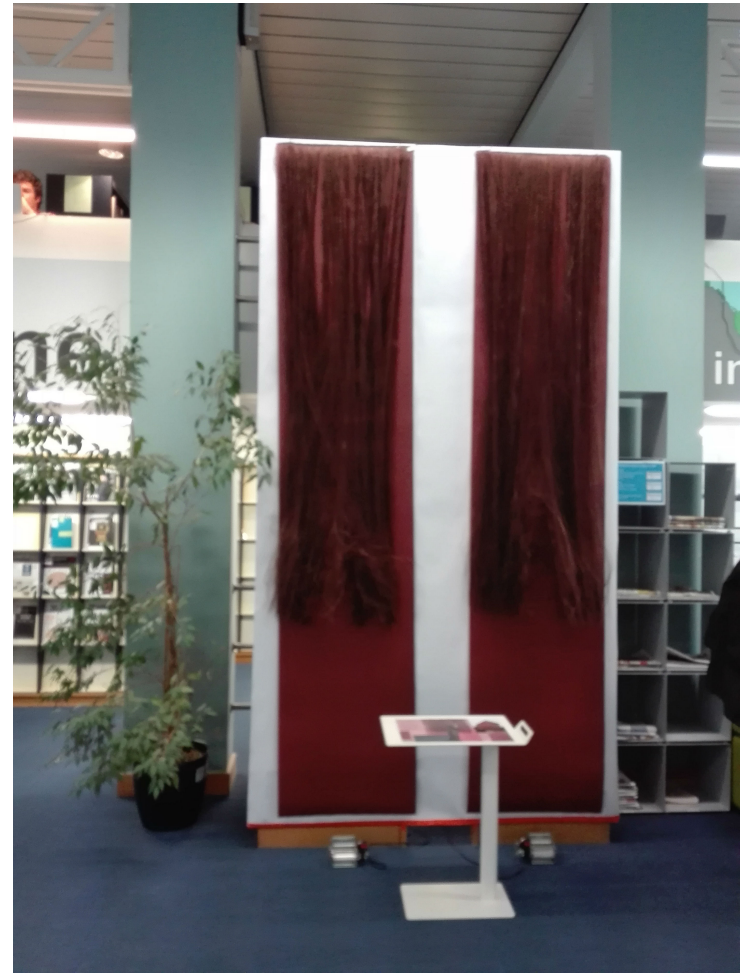

Installation, Monik Myle

Figure 5. Series of art works created in the context of the research. Photographs courtesy of the involved art students. 
The students also shared experiences using a blog to post links, memos, background information, photos of the neighborhood or photos of their work in process. With the making of these art works, we not only aimed to record data (in terms of collecting visuals and other sensory materials that represent the neighborhood in flux) but we tend to make data from an embodied engagement with the sensory qualities of the world (Cahnmann-Taylor \& Siegesmund, 2018). As such, the art works made in the context of the study were used to generate new data. These data can be considered as narratives of place experiences, narratives that are not verbal but that can "take many forms, depending on the individuals involved and the contexts they derive from" (Cele, 2006, p. 14). Depending on the student's artistic background, several creations were made, including photographic work, a video made out of still images, installations made out of recycled materials, paintings and drawings (see Figure 5).
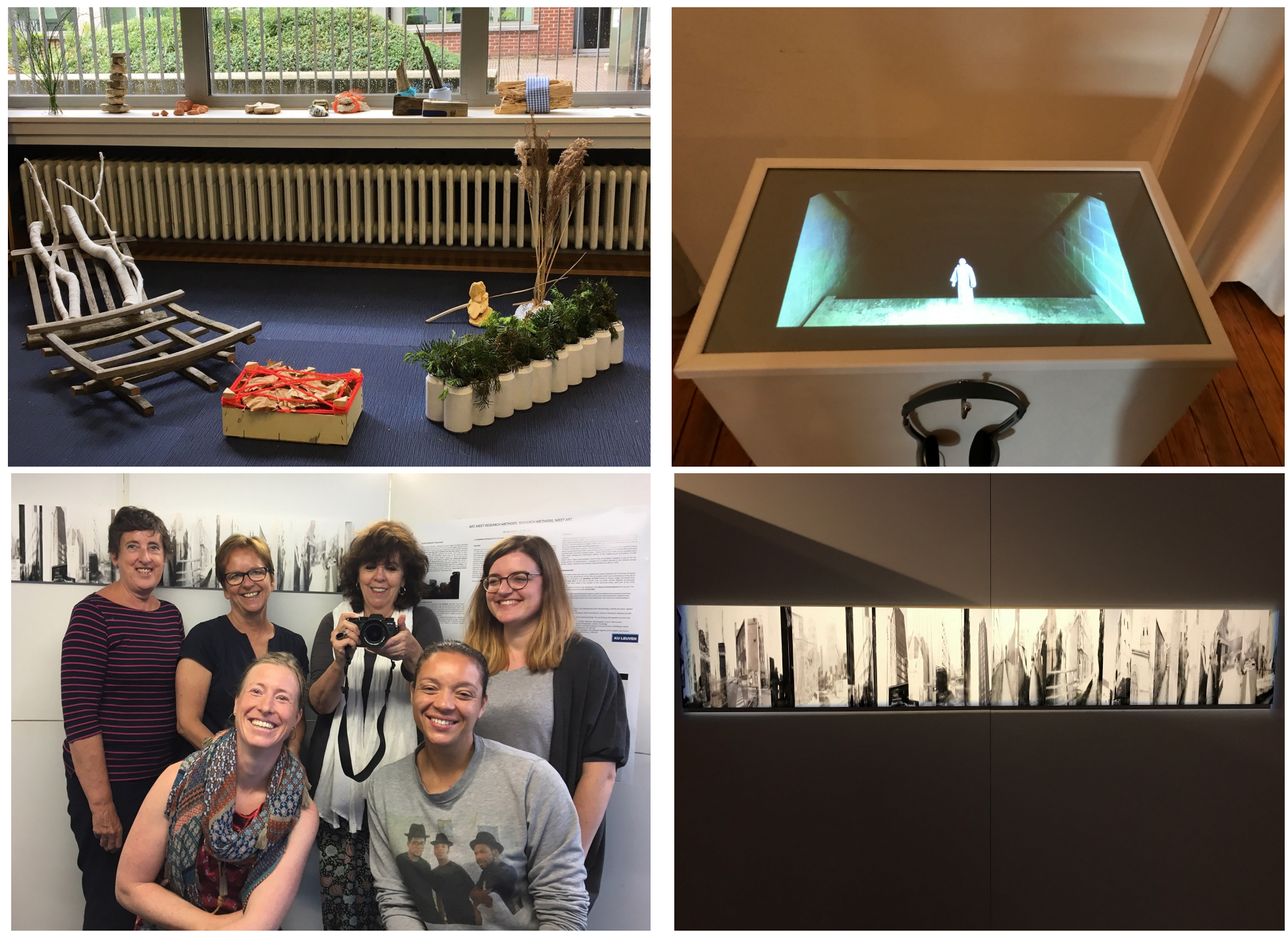

Figure 6. Expositions. Photographs courtesy of Annemie Moriau and Christiane Aerts. 
Stage 4: Disseminating. As Dewey argues, a work of art is something that is experienced. This experience is what the product created does. As such, a work of art, an artist and its audience form an important triad: for a work of art to be complete it needs to be experienced by an audience (Leddy, 2016). This study culminated in an exhibition at STUK (House for Dance, Image and Sound) in May 2017 in the city of Leuven. A selection of 21 art works that were made based on the research collaborations between art students and researchers involved in the PiLoT1 project were displayed at this event. The works made in the context of our specific project were presented under the joined label "Si(gh)tes of necessary trouble." Afterward, our series of art works were displayed at the Library of Social Sciences, KU Leuven (June, 2017). Both dissemination events (see Figure 6) were meant to challenge traditional conventions on academic research writing that "transform multi-register eventassemblages into the unidimensional medium of written text" (Fox \& Alldred, 2015, p. 173). Moreover, it enabled us to pull a diverse audience into the research assemblage.

\section{Analyzing Sense Data from a Material-Discursive Perspective}

In the aftermath of PiLoT1, we continued to work together with the art students to explore an analytical lens that would do justice to the material aspects of the research and how these were linked to the discursive evidence. We embraced a flattened research logic "where discourse and matter are mutually implicated in the unfolding emergence of the world" (MacLure, 2013, p. 660).

\section{Conceptualizing the Analytical Apparatus}

Inspired by the quality framework introduced by Dewey (1934), Eisner (1972), and further rephrased by Siegesmund (2012), we illustrate how art work qualities can be brought in as an equal player in analytical research exercises, rather than being put to the service of the discursive process, as is often the case in many research projects.

Art work qualities include elements and principles of the design. Elements are the foundational blocks of an art creation. They include shapes, forms, spaces, color, texture. Color and texture are for instance elements that engage the senses directly. Colors focus the attention on particular aspects of the work. They can be used to connect or disconnect different objects and make associations between them, which can create relations of harmony or conflict. The use of different textures can give visuals, for instance, a tactile or "touchable" quality. Textures can evoke smoothness, roughness, slipperiness, softness, and so on. These effects can be repeated or contrasted within the art works (Hook \& Glăveanu, 2013). The principles of design refer 
to how the building blocks are used in the particular design. Examples of principles include balance, emphasis, movement, repetition, proportion, rhythm, variety, and unity.

During individual conversations with every art student, the lead author brought in the art work qualities as a material-discursive analytical framework. During these conversations, she asked the art student to reflect on the following qualities:

(1) elements such as lines, shapes, colors, textures,

(2) principles such as movement, balance, contrast, patterns,

(3) materials used, such as paint, wood, metal, and paper.

Students were asked to relate these art work qualities to the experiences he or she gained while being active in the neighborhood. This framework brought in a vocabulary close to the materiality of the art work. It enabled us to develop a language that corresponded to the art students' felt somatic experiences (Hannes, 2018).

As a result, we could look at the art works in relation to the creative process that has been taken place, and in relation to the involved student and his/her experiences. This gave us a better understanding where the work came from and what the art student did with the material in response to the neighbourhood under research. As such, the material-discursive analytic lens allowed us to enrich, extend, or challenge the analysis and peel back deeper understandings of the art works (Hannes, 2018), combining the material and the discursive. The lead author also integrated insights from the walking interviews into the aesthetic storyline of the art works. ${ }^{1}$ An illustration of this process is presented below.

\section{Applying the Analytical Apparatus}

In what follows we will apply the analytic lens developed on the works of art created by two of our participating art students. We use the elements and principles of design as the main framework for the analysis, hereby looking at art work qualities that demand our attention. This worked example illustrates how a close reading of two installations stimulated us to link matter to meaning and to render the changing city as a sensuous milieu (Manning, 2009). In doing so, we hoped to attend to configurations where diverse bodies, things, affect, desire, matter, and imagination collide to create new entanglements and also new possibilities for the city (Gannon, 2016). Member checks were achieved by having the involved art students validate the analysis.

"Twisting tower." Monik created an installation wherein one question was of massive importance: Who has the authority to decide how others have to live their life? 
The main source of inspiration for this work is the Twist Tower, a "tower" built by architect Stéphane Beel in the "Tweewaters" district in the Canal Bowl area. The Twist contains more than forty apartments and got its name through its "twisted" shape. By means of a refined nuance of the glass windows in the tower, the two façades look like each other's inverted mirror image (Tweewaters, 2012). Intrigued by this building, Monik started to explore what this building tells her about this part of the city and how this picture shaped her general impression of the neighborhood. During the go-along interview, she argued that "it is a fantastic area to photograph, the view is beautiful... it looks like a postcard... but you don't feel the people... I don't want to live here..." For her, the tower didn't "twist" enough and the search for a different type of twist became central to her inquiry (Table 1).
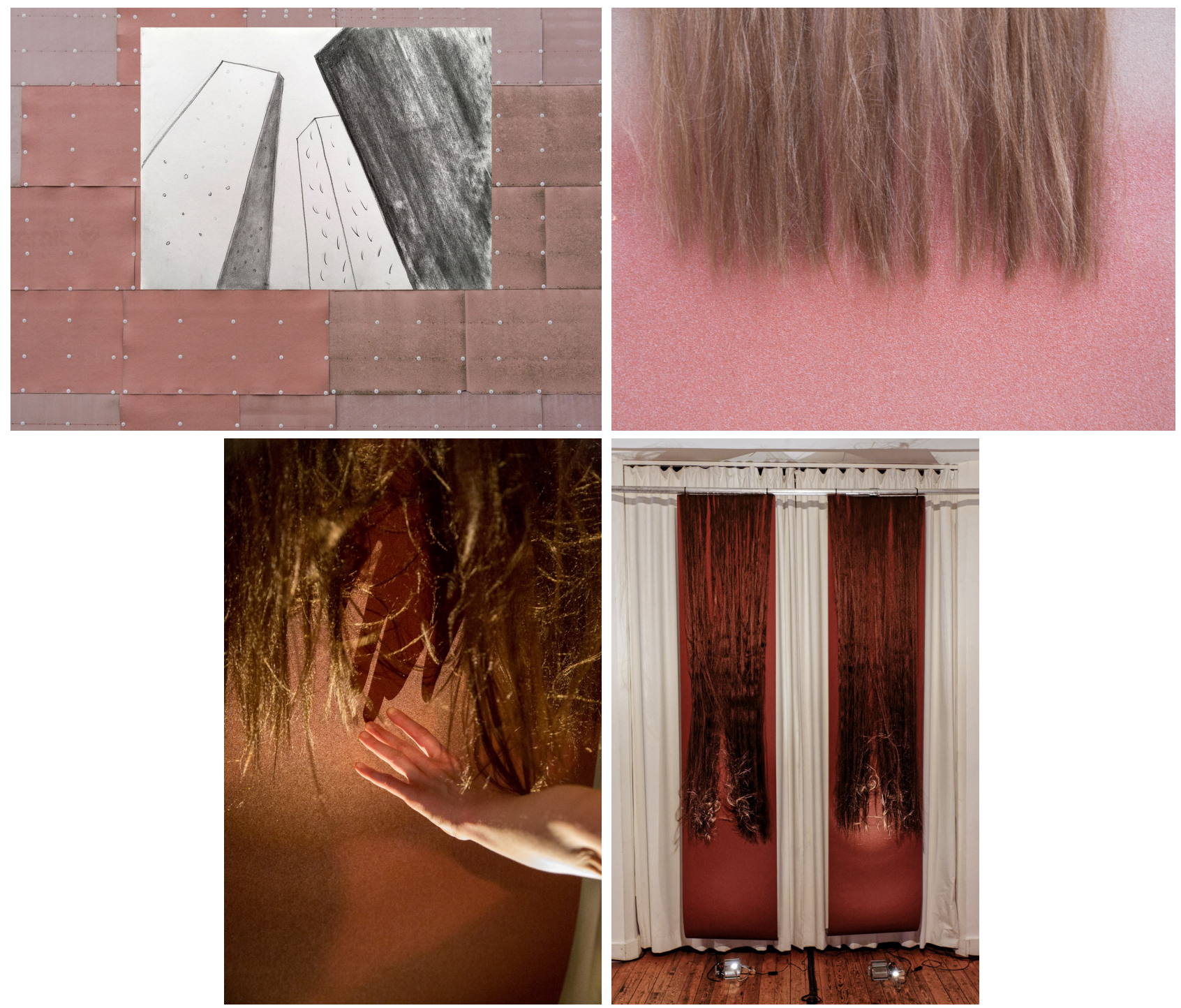

Figure 7. Twisting tower. Photographs courtesy of Monik Myle. 
Table 1

Twisting Tower Installation by Monik

\begin{tabular}{|c|c|}
\hline Lines & $\begin{array}{l}\text { The installation (see Figure 7) appears to be characterized by } \\
\text { the use of vertical lines. The use of these vertical lines may } \\
\text { evoke a certain aesthetic quality; stressing force. Monik already } \\
\text { talked about this verticality during the go-along interview: "it's } \\
\text { this verticality and I don't really like it... it reminds me of Gothic } \\
\text { art and I'm not really a fan of it. I'd rather prefer Romanesque } \\
\text { art which is horizontal and in line with the landscape. But in } \\
\text { Gothic art at least they used this verticality to worship God. But } \\
\text { what's the use of this verticality here in the Canal Bowl? Who is } \\
\text { God here? I guess it is the money..." One can interpret the } \\
\text { verticality used in the installation to express a certain force that } \\
\text { is also present when walking through the area across the high } \\
\text { buildings: "it feels like the buildings are always above my head, } \\
\text { you just have to look up, you have to look at the sky..." For } \\
\text { Monik, this is rather an oppressive feeling. }\end{array}$ \\
\hline Shapes & $\begin{array}{l}\text { The shapes that were used are kept very simple. She attached } \\
\text { two large rectangular strips ( } 3,3 \text { meters) of sandpaper to a wall. }\end{array}$ \\
\hline $\begin{array}{l}\text { Texture } \\
\text { Material }\end{array}$ & $\begin{array}{l}\text { To make the installation, she experimented with different types } \\
\text { of materials. Sandpaper was eventually chosen because of its } \\
\text { specific texture that reminded her of her walking experience. } \\
\text { She associated the texture of the buildings and their color with } \\
\text { sandpaper: "At a particular moment during the walk, I was } \\
\text { asked to touch those new bricks... I immediately had the feeling } \\
\text { that I did not want to do that, it reminded me of sandpaper so I } \\
\text { didn't want to feel that. And yes, sandpaper also has a red } \\
\text { color." The texture of the buildings triggered her to further } \\
\text { reflect upon the neighborhood and how she experienced the } \\
\text { walk. She also associated this texture with goosebumps. } \\
\text { Because the walk took place on a particularly cold winter day it } \\
\text { was an excellent translation for the literal coldness she } \\
\text { experienced during the walk. Moreover, thinking about the } \\
\text { concept of goosebumps triggered a general feeling towards this } \\
\text { neighborhood: She felt that "human skin" was exactly the thing } \\
\text { that was missing in this area. She argued that "there is a lack of } \\
\text { liveliness at the moment, you could say that there is no human } \\
\text { skin (...) and I believe that the architecture must come from the } \\
\text { people that live there... I understand that architects and city } \\
\text { developers must exist, but there is the tendency to just drop }\end{array}$ \\
\hline
\end{tabular}




\begin{tabular}{|c|c|}
\hline $\begin{array}{l}\text { Texture } \\
\text { Material } \\
\text { (cont'd) }\end{array}$ & $\begin{array}{l}\text { people... too much planning involved." So this lack of human } \\
\text { skin was exactly the thing that she missed in this neighborhood } \\
\text { and what she wanted to portray in her creation. It was an } \\
\text { attempt to give the towers a more humane character. She } \\
\text { explored different types of sandpapers to remain close to her } \\
\text { sensorial experience during the walk. A rough texture of } \\
\text { sandpaper was eventually chosen: "I chose rough sandpaper } \\
\text { because soft sandpaper would not make any sense. For me, it } \\
\text { is the awful feeling of this coarse texture." }\end{array}$ \\
\hline Color & $\begin{array}{l}\text { To choose the right color for the sandpaper, she slightly } \\
\text { deviated from what she saw during the walk: "The red color still } \\
\text { matches the brick and still slightly differs from the goosebumps, } \\
\text { the color is between red, the color of the bricks and pink, the } \\
\text { color of the skin." }\end{array}$ \\
\hline Material & $\begin{array}{l}\text { Elaborating on this concept of skin she also added hair as an } \\
\text { organic material to her installation, reinforcing the more humane } \\
\text { character of the building: "I've used hair to connect it with the } \\
\text { people." Monik bought the hair in the Matongé neighborhood, } \\
\text { an African quarter in Brussels characterized by its many local } \\
\text { restaurants, cafés, and its African hair salons. It is an interesting } \\
\text { choice since Monik already made a link to Africa during her go- } \\
\text { along interview: "for me, this neighborhood looks a little bit } \\
\text { absurd, here you see a bridge, there you see cars driving, there } \\
\text { you see this gigantic building towers... but it seems like... it } \\
\text { seems like there is no connection with the people. There is no } \\
\text { central issue where things revolve around. If you compare this } \\
\text { for example with Africa... When cities begin to develop, it } \\
\text { always starts around someone who does something, for } \\
\text { instance, someone who makes and sells tires, and then } \\
\text { somebody else who sells gasoline and so on... That's how } \\
\text { cities grow, they gradually develop. Here it just pops out of the } \\
\text { ground." }\end{array}$ \\
\hline Contrast & $\begin{array}{l}\text { Hence, we may look at the installation as a contrast that is } \\
\text { being created by the use of roughness (the rough texture of the } \\
\text { sandpaper) and softness (the use of hair). This may create a } \\
\text { visual tension between what is and what ought to be. }\end{array}$ \\
\hline
\end{tabular}




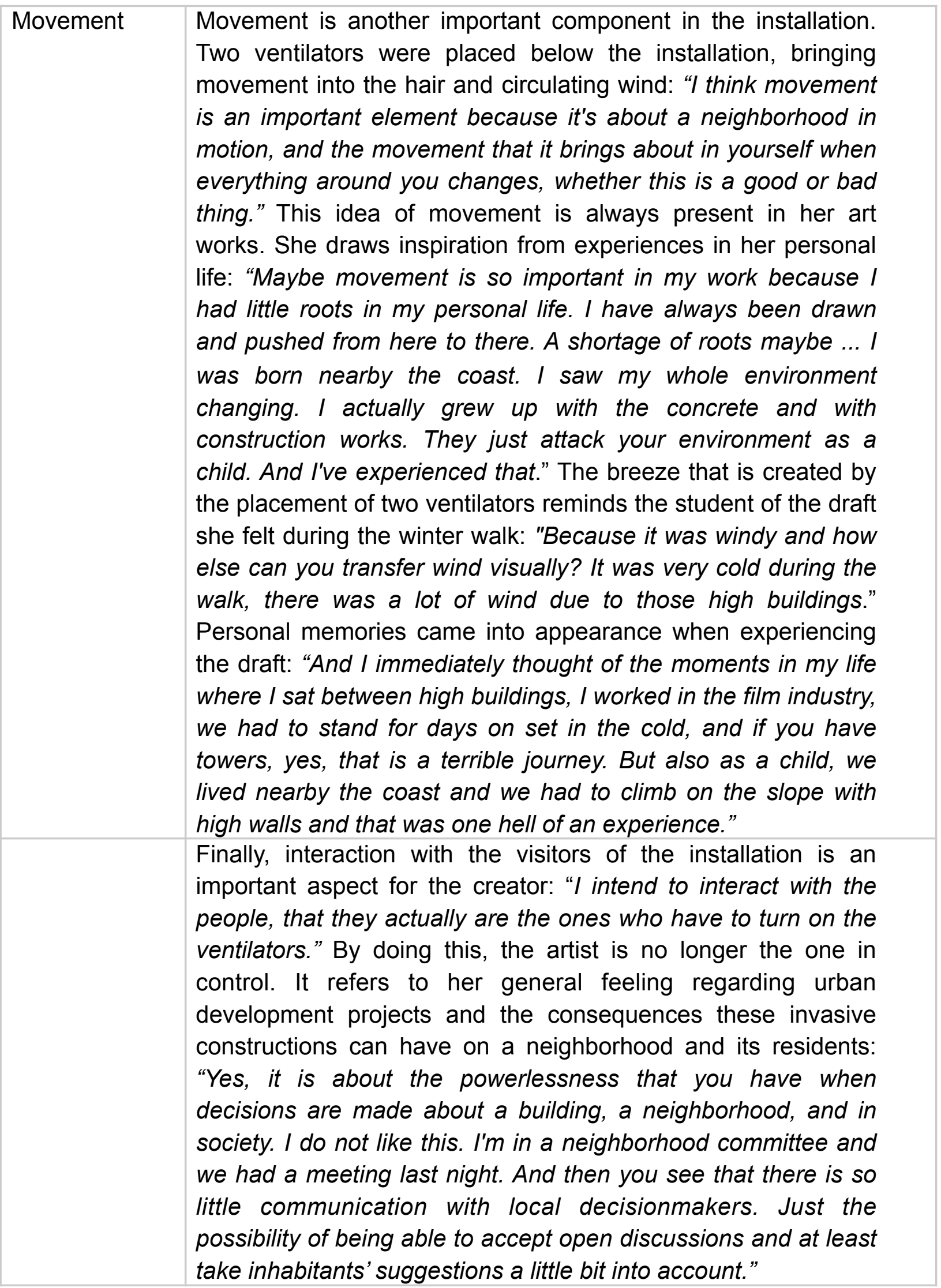


"A new order." Christiane made multiple walks in the area. These strolls became searches for order in chaos, the chaos in the Canal Bowl area, as she stated: "The area underwent and undergoes changes, the area is in full transformation, with chaos as a result; rubble, buildings, familiar images that are disappearing, new greenery that still has to grow... How do we relate to those changes? How can we look at a neighborhood in change?" Specific spots caught her attention and triggered emotions or memories that she captured in images. In the artistic process, she intra-actively engaged with her photographs. Sketches (see Figure 8) were created that changed the essence of the original images through the use of compositional elements: amplification of colors, manipulation of size, intensity, tracing contours, replacement of elements (Hannes, 2018)
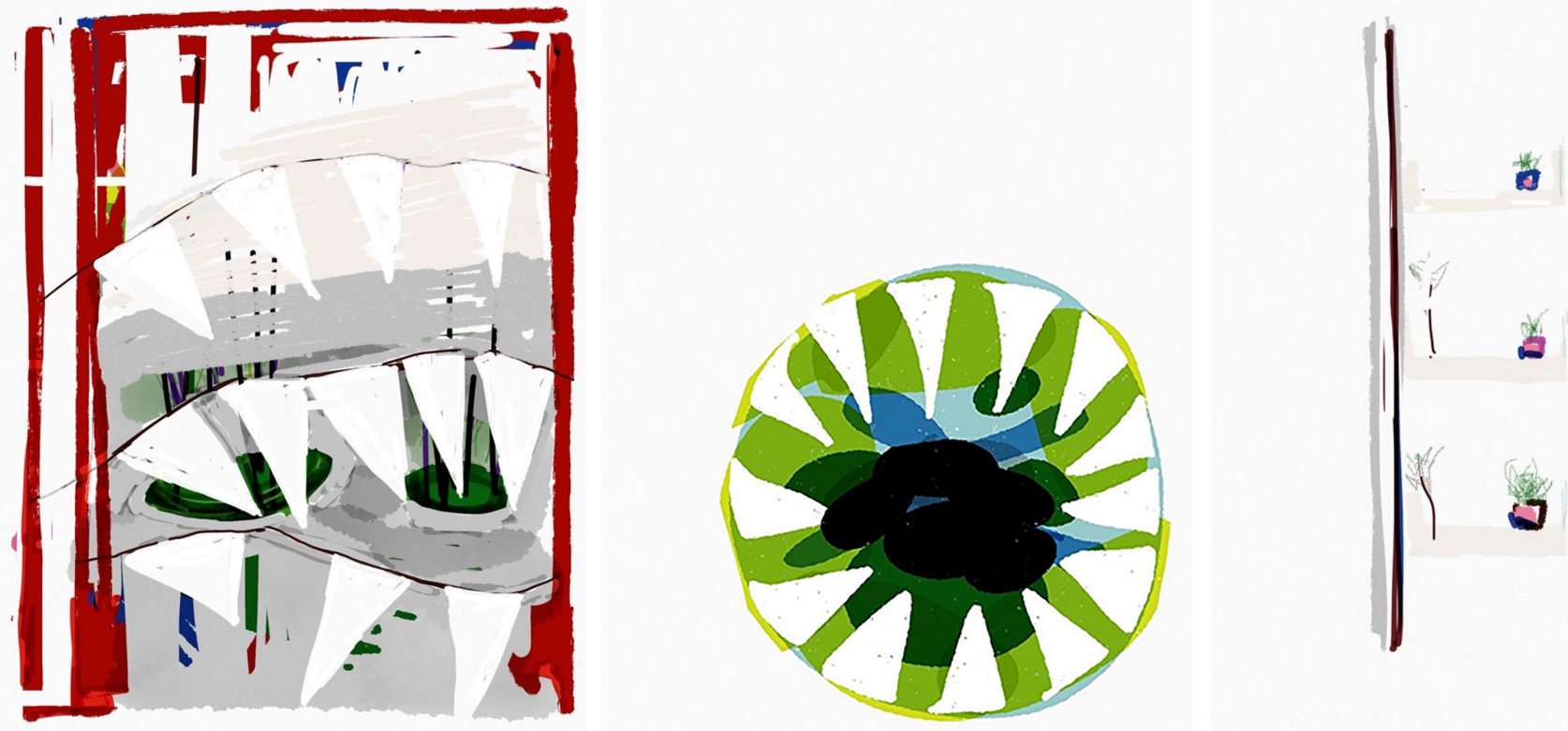

Figure 8. Sketches. Photographs courtesy of Christiane Aerts.

She went back to her locations of interest several times. What followed was a tactile exploration of the changing neighborhood, the objects, and materials she encountered during the walks. She collected objects that others discard or pass by carelessly. These were transformed into an art installation (see Figure 9 \& Table 2): "Depending on the location I created something out of the ordinary elements available in the environment that normally don't catch human attention." For this work, she made use of diverse materials that triggered her imagination: "It is not the reality but the reality imagined, the imaginary overcomes and creates a new kind of order in the chaos." 


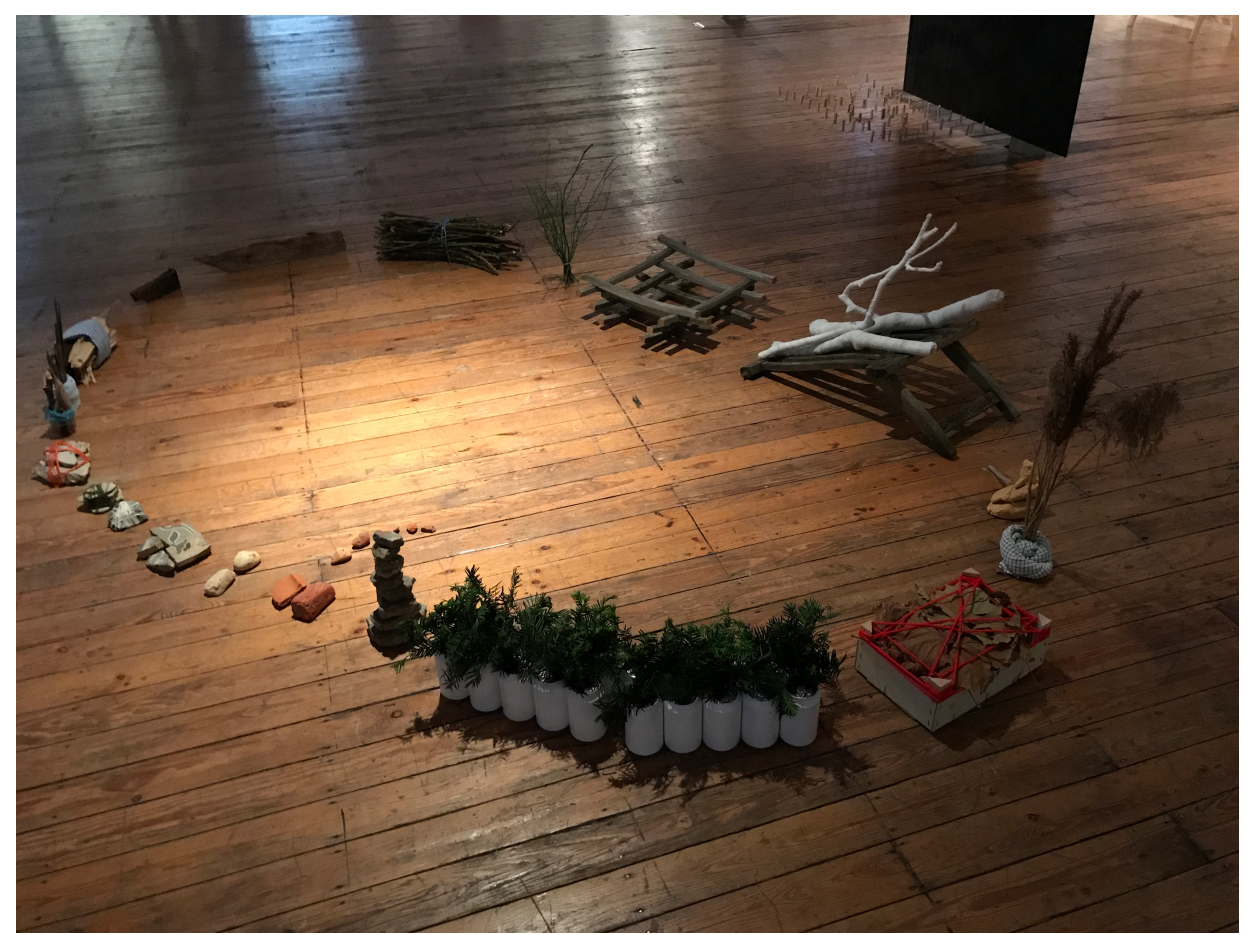

Figure 9. A new order. Photograph courtesy of Annemie Moriau.

Table 2

A New Order by Christiane

\begin{tabular}{|l} 
Unity \\
Unity can be interpreted as being an overall important principle in \\
the art installation, the order in the composition appears to give \\
harmony to the global picture and to evoke a certain rhythm, with \\
which she started to play: "I tried to play with it, I have put the \\
elements in different sequences, from small to large, from stones \\
to branches..." \\
All the materials she used came from the neighborhood, \\
including rubbish (ropes and cans that were left behind by \\
people) and organic materials (such as stones, leaves, and \\
wooden branches). With these materials she wanted to create \\
something new: "I'm going to extract elements, isolate, recover, \\
rearrange, label, organize. The elements are removed from their \\
environment and placed in a different context and, as a result, \\
they obtain a new order." For Christiane, the re-use of found \\
materials was a way to cherish the past; to work with objects and \\
things that were still there, before the trucks would have taken \\
them all away as part of the urban renewal process: "Once they
\end{tabular}




\begin{tabular}{|ll|}
\hline $\begin{array}{l}\text { Materials } \\
\text { (cont'd) }\end{array}$ & $\begin{array}{l}\text { start coming with lorries to take away the rubble, it might also be } \\
\text { Color }\end{array}$ \\
\hline Christiane worked with a variety of colors to create this new \\
order. Every material she re-used was labeled with a particular \\
color: "The wood received a blue label. For example, I painted a \\
blue stripe on the wood, or I tied a blue rope around it, and these \\
stones were labeled with an orange color ... and these white \\
because that's another kind of stones... and so I clustered them \\
all together." The repeated use of these color elements was a \\
crucial feature of the installation, it created a certain rhythm, a \\
certain pattern, and associations as will be explained below.
\end{tabular}

In the process of making the art work, several small creations were made that can be linked to particular locations she photographed. Christiane designed "visual image pairs" (Marin-Viadel, Roldan, Genet, \& Whiston Spirn, 2015) that are composed of two images: the initial photograph taken at a specific location (the left picture as illustrated in Figure 10) and the photograph of her creation inspired by that particular location (the right picture as illustrated in Figure 10). They are joined to one another to construct an argumentation based on her sensorial experiences. Below we discuss one of the visual image pairs that was part of the installation in more detail (Table 3 ).
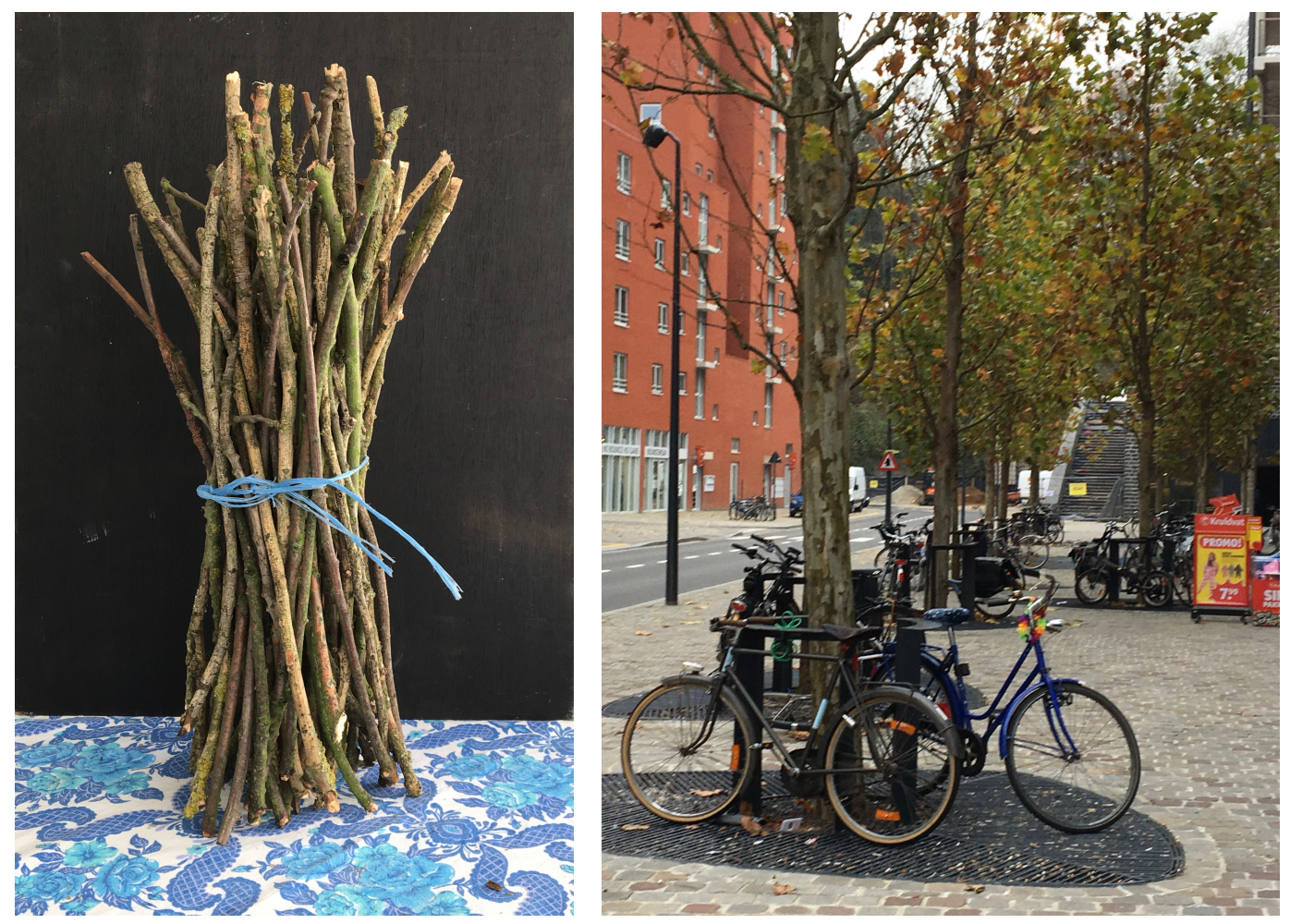

Figure 10. Visual image pair. Photograph courtesy of Christiane Aerts. 
Table 3

Visual image pair made by Christiane

\begin{tabular}{|l|l|}
\hline emphase & $\begin{array}{l}\text { We could look at the photograph at the right as having a good } \\
\text { figure-ground relationship. The most important aspect of the } \\
\text { picture is clearly recognizably placed in the center of the } \\
\text { photograph. The size of the figure and its contrast with the black } \\
\text { background increases its recognizability. }\end{array}$ \\
\hline Shape & $\begin{array}{l}\text { One can interpret the photograph of the initial location at the left } \\
\text { and the picture of the creation at the right as being clearly } \\
\text { connected to each other. This appears to become obvious } \\
\text { through the use of picture elements that are similar to one } \\
\text { another in shape and color. The figure in the second picture } \\
\text { consists of a bundle of wooden branches. It has the same shape } \\
\text { as the tree standing in the foreground in the left picture. The } \\
\text { wooden branches are kept firmly together by a blue rope. }\end{array}$ \\
\hline Color & $\begin{array}{l}\text { The color of this rope appears to be important for two reasons. } \\
\text { First of all, in her installation, she worked with a variety of colors } \\
\text { to create a new order. Every material she re-used was labeled } \\
\text { with a particular color and clustered together based on these } \\
\text { particular colors. Wood was labeled as blue in the installation. } \\
\text { Second, the color blue is chosen for a specific reason. It } \\
\text { connects the creation with her original location. The color blue is } \\
\text { also visible in the first photograph of the investigated place, } \\
\text { where a blue bicycle is visible at the front. Moreover, the table- } \\
\text { cloth in the second picture does not only have the same blue } \\
\text { color as the rope, there is a similarity with the ground portrayed } \\
\text { in the first picture: both have a clear pattern. The chaotic print of } \\
\text { table-cloth may resemble the texture of the stones visible in the } \\
\text { first picture. }\end{array}$ \\
$\begin{array}{l}\text { For the participant, this image resonates with her image of the } \\
\text { city Leuven: "It's so typical for Leuven, these bicycles that stand } \\
\text { around that pole and that red building in the background... } \\
\text { "During the walk she talked about this: "having a mix of old and } \\
\text { young people also influences the street scene... in this city, } \\
\text { everywhere you go you see bikes, bikes, bikes,... when you're } \\
\text { older or with imperfect eyesight, that's a problem...it really } \\
\text { hinders pedestrians." }\end{array}$ \\
\hline Pattern
\end{tabular}




\begin{tabular}{|l|l|}
\hline Texture & $\begin{array}{l}\text { The trees in the picture also caught her attention: "...when I } \\
\text { looked more closely at the trees I got the idea that these trees } \\
\text { needed to be trimmed. So that's what I wanted to portray in my } \\
\text { creation. That's why I used pruning wood that I found in the } \\
\text { area." When literally feeling these wooden branches and making } \\
\text { this composition, it also reminded her of her childhood: "In the } \\
\text { past, people would never leave good branches like these laying } \\
\text { on the streets. They would tie an iron wire around it. That was } \\
\text { the stock for the firewood. To stir up the fire. So when I came } \\
\text { home with all those branches after my walk in the neighborhood } \\
\text { I started to bundle them all together. For good old's sake" }\end{array}$
\end{tabular}

\section{Discussion}

In this paper, we described a sensory research project in which the potential of a material-discursive analytical apparatus was explored. Cutting across matter/ meaning (Fox \& Alldred, 2015), we used a variety of approaches in different stages of the research process. In each of these phases, we, the researchers, or the artists alternately took the lead.

First, we introduced go-along interviews that would allow us to focus more easily on the physical aspects of the place under research that were triggered by what can be seen, touched, heard, smelled, etc. We walked the Canal Bowl area in the company of four student-artists, focusing on the mundane, often ignored features of the streetscape (O'Neill \& Hubbard, 2010). The diverse elements in the urban environment, such as the wind, the smell, buildings, wood, stones, branches, bicycles, cars, and ropes possessed an affective, vibrational force. They acted, as Taylor (2017) argues, "in a kaleidoscopic confederacy [that] create[d] the texture, atmosphere, mood and affects" (p. 8) which condition what a changing neighborhood is and means, but also what it does and how it is experienced.

Second, this interaction between material and discursive dimensions of understanding place experiences also became central in the creation-responding phase. In this stage, the art students were in charge and created a response based on their sensory experiences of the walks and the transcripts produced by us. The art students' encounters with material things during the walks left an affective mark on them, which invited them into an act of creation. This phenomenon, where things are considered to have agency is explained by Bennett (2010) as the power of things. According to Bennett, things are not awaiting a response from humans but actually generate a response by issuing a call for attention. Recognizing the power of things, the 
art students allowed themselves to be amazed by what they saw, felt, heard, and smelled. They followed their senses in the exploration of the changing neighborhood. The art works conveyed something of the feel of urban places and captured some of their sensory richness (Rose, 2016). The making of these works in the context of this research implies that we need to acknowledge the co-constituting character of inquiry; how the medium in which we work shapes us as inquiring subjects as much as we shape it (Rosiek, 2018). The device used is never neutral, as the examples of Christiane and Monik showed us. Photo cameras, paintbrushes, pencils... all played a particular role in the sense-making process (Siegesmund, 2018). Involved in a process of image iteration, Christiane for instance began to actively change the relationships of art work qualities in her installation, and in so doing facilitate the emergence of new perspectives.

Third, introducing material dimensions of place experiences also had its implications for data analysis. In this stage, we introduced our material-discursive lens in individual conversations with the art students to analyze the art works together. In doing this, we brought the art works to the center of the analytical process hereby attending to the fleeting, manifold, and affective intensities of the changing environment (Springgay \& Truman, 2018). It resulted in an engagement to be with the creations (Clark/Keefe, 2014). Rather than distinguishing between language and matter, the analytical apparatus considered them in interaction (Taylor, 2017). Based on our experiment with this material-discursive apparatus, we argue that art works can do more than illustrate ideas produced through dialogical encounters between researchers and participants. They bring matter and its intrinsic qualities to the foreground, hereby recognizing that matter is always part of meaning. With the analysis presented in this paper we do not have the intention to provide a full translation of the meaning within the art works. We are fully aware that data are always made by participants and re-formed by researchers who search for patterns and display the data in a particular way to make a case for the research topic (Riddett-Moore \& Siegesmund, 2012). What we do argue is that the material-discursive analytical apparatus enables us to start a dialogue between the material and the human, grounding the interpretation in the created art work itself (Tuck \& McKenzie, 2015).

Moreover, the material-discursive lens enabled us to look at the art works not only as expressions of what individual art students had experienced. The art works provided us with a particular language to speak about the studied environment and to open up a discussion about how it could evolve. Through this lens, the art works became ethnographic and political concepts that manifested collective issues (Siegesmund, 2012) relating to urban regeneration being experienced by many cities around the world. The art works visualized particular matters of concern. The way urban spaces are built or re-generated sensorially has an impact on how certain practices and 
people are in, or excluded from, the city life (Low, 2015). In the Canal Bowl, it visualized the often market-driven logic of urban infrastructural design that is now dominating neighborhood development processes. This is often applied in a top-down manner by powerful decision makers, neglecting various human and non-human voices in a democratic debate about the kind of city we want. In both works portrayed in this paper, the "neglected voice" becomes visible. Christiane's work was, for example, an attempt to call attention to objects that others discard or pass by carelessly before they are removed as part of the urban renewal process. The lack of "human skin," a metaphor used by Monik to refer to a city without a soul, speaks towards the same theme.

Finally, in the dissemination phase, the art students were the ones in charge of the exhibition in close collaboration with the curator (for the STUK exhibition) and the researchers.

This approach, in which the pioneering role of researchers and art students alternated throughout the various stages of the research process, encouraged us to think about how researchers and artists can collaborate at the boundaries of their fields of practice that may already be interlinked (Pink, 2009). Artists and researchers working in urban neighborhoods are often interested in the same type of questions; how do we live and how can the study of living help us to imagine new futures? While doing this, both give close attention to the empirical world. One of the main differences is that we as researchers are more used to distance ourselves from the world. Artists, however, are used to working directly in materiality and to think in terms of the medium:

Artists understand what it means to negotiate with materials - with stone, metal, or ink pooling in absorbent paper. Advanced training in the arts - past the basic skills of technique and control - largely deal with strategies for negotiating with the non-human. Therefore, the arts may suggests way of thinking in material that could be fruitful to new ways of conducting postqualitative research. (Siegesmund, 2018, p. 102)

As such, artists can help researchers to see interesting ways of looking at the world, explore possible modes of being or destabilize existing modes of being (Rosiek, 2018). Artists can show us ways to recognize aesthetic qualities. However, engaging with such qualities should not be the monopoly of artists. In line with Dewey's view on aesthetics, it should be much wider in scope. Thinking in terms of qualities does not necessarily start with connoisseurship, it rather starts with a reflection on how we live, interact and move in everyday life (Siegesmund, 2017). 


\section{Author Contributions}

Karin Hannes and Sara Coemans conceptualized, managed, and carried out the research. Sara Coemans conducted and analyzed the individual interviews together with the artists, drafted and finalized the paper. Joke Vandenabeele gave critical comments throughout the process. All authors discussed the main ideas and contributed to the final manuscript.

\section{Acknowledgements}

We are grateful to the participating art students, Annemie Moriau, Christiane Aerts, Monik Myle, and Patrick de Nys, from the fine arts department of SLAC. Special thanks are also extended to Sociology student Tamara Lodder, who has been actively involved in different phases of the research project. We would like to thank them all for their enthusiasm, time, and commitment invested in the project. The analytical work was also deepened by conversations with Prof. Dr. Richard Siegesmund during his stay at the University of Leuven in the context of a visiting fellowship. 


\section{REFERENCES}

Anderson, J. (2004). Talking whilst walking: A geographical archaeology of knowledge. Area, 36(3), 245-261.

Anderson, J., Adey, P., \& Bevan, P. (2010). Positioning place: Polylogic approaches to research methodology. Qualitative Research, 10(5), 589-604. doi: $10.1177 / 1468794110375796$

Baldacchino, J. (2014). John Dewey. Liberty and the pedagogy of disposition. New York, NY: Springer.

Bennett, J. (2010). Vibrant matter: A political ecology of things. London, UK: Duke University Press.

Carpiano, R.M. (2009). Come take a walk with me: The go-along interview as a novel method for studying the implications of place for health and well-being. Health \& Place, 15(1), 263-272. doi:10.1016/j.healthplace.2008.05.003

Cele, S. (2006). Communicating place. Methods for understanding children's experience of place. (Doctoral thesis). Stockholm University, Department of Human Geography.

Clark/Keefe, K. (2014). Suspended animation. Attuning to material-discursive data and attending via poesis during somatographic inquiry. Qualitative Inquiry, 20(6), 790-800. doi:10.1177/1077800414530263

Cahnmann-Taylor, M. \& Siegesmund, R. (2018). Arts-based research in education. Foundations for practice (2 $2^{\text {nd }}$ edition). New York, NY: Routledge.

Chilton, G., \& Leavy, P. (2014). Arts-based research practice: Merging social research and the creative arts. In P. Leavy (Ed.), The Oxford handbook of qualitative research (pp. 403-422). New York, NY: Oxford University Press.

Dewey, J. (1934). Art as experience, Rahway, NJ: The Barnes Foundation Press.

Eisner, E. W. (1972). Educating artistic vision. Oxford, UK: Macmillan.

Evans, J. \& Jones, P. (2012). The walking interview: Methodology, mobility and place. Applied Geography, 31(2), 849-858. doi:10.1016/j.apgeog.2010.09.005 
Fox, N. J. \& Alldred, P. (2015). New materialist social inquiry: Designs, methods and the research-assemblage. International Journal of Social Research Methodology, 18(4), 399-414. doi:10.1080/13645579.2014.921458

Gannon, S. (2016). Local girl befriends vicious bear: Unleashing educational aspiration through a pedagogy of material-semiotic entanglement. In C. A. Taylor \& C. Hughes (Eds.), Posthuman Research Practices in Education (pp. 128-148).

Hannes K. (2018). Applying SQUID in photovoice research: An aesthetic apparatus for image data analysis. Presented at the International Congress of Qualitative Inquiry, Champaign.

Hook, D. \& Glăveanu, V.P. (2013) Image analysis: An interactive approach to compositional elements. Qualitative Research in Psychology, 10(4), 355-368. doi: 10.1080/14780887.2012.674175

Hurdley, R. \& Dicks, B. (2011). In-between practice: Working in the 'thirdspace' of sensory and multimodal methodology. Qualitative Research, 11(3), 277-292. doi: 10.1177/1468794111399837

Johnson, M. (2007). Dewey's zen: The 'oh' of wonder. Society for the Advancement of American Philosophy, Columbia, SC.

Karel, E. (2013). Ernst Karel. Retrieved from https://earroom.wordpress.com/ 2013/02/14/ernst-karel/

Kusenbach, M. (2003). Street phenomenology: The go-along as ethnographic research tool. Ethnography, 4(3), 455-485. doi:10.1177/146613810343007

Leddy, T. (2016). Dewey's Aesthetics. The Stanford Encyclopedia of Philosophy. Retrieved from https://plato.stanford.edu/archives/win2016/entries/deweyaesthetics/

Leuven MindGate (2018). Creativity. Retrieved May 4, 2018, from https:// www.leuvenmindgate.be/about-leuven-mindgate/health-high-tech-and-creativity/ creativity

Low, K.E.Y. (2015). The sensuous city: Sensory methodologies in urban ethnographic research. Ethnography, 16(3), 295 - 312. doi:10.1177/1466138114552938 
MacLure, M. (2013). Researching without representation?: Language and materiality in post-qualitative methodology. International Journal of Qualitative Studies in Education, 26(6), 658-667. doi:10.1080/09518398.2013.788755

Mandanipour, A.(2001). How relevant is planning by neighbourhoods today? Town Planning Review, 72(2),171-192

Manning, E. (2009). Relationscapes: Movement, art, philosophy. Cambridge, MA: MIT Press.

Marin-Viadel, R., Roldan J., Genet, R., \& Whiston Spirn, A. (2015). Visual arguments through visual image pairs and photo pairs in arts based research and artistic research on childhood and art education. 1st Conference on Arts-Based and Artistic Research, Porto, Portugal.

Missotten, G. \& Desmet, L. (2010). Vaartkom Weerspiegeld. Leuven, BE: Stad Leuven.

O’Neill, M. \& Hubbard, P. (2010). Walking, sensing, belonging: Ethno-mimesis as performative praxis. Visual Studies, 25, 46-58. doi:10.1080/14725861003606878

Pink, S. (2007). Sensing Cittàslow: Slow living and the constitution of the sensory city. Sense and Society, 2(1), 59-77. doi:10.2752/174589207779997027

Pink, S. (2009). Doing sensory ethnography. London, UK: Routledge.

Pink, S., Hubbard, P., O’Neill, M. \& Radley, A. (2010). Walking across disciplines: From ethnography to arts practice. Visual studies, 25(1), 1-7. doi: 10.1080/14725861003606670

Rose, G. (2016). Visual methodologies: An introduction to researching with visual materials. Thousand Oaks, CA: Sage.

Rosiek, J.L. (2018). Art, agency, and inquiry: Making connections between new materialism and contemporary pragmatism in arts-based research. In M. Cahnmann-Taylor \& R. Siegesmund (Eds.), Arts-based research in Education (pp. 32-47).

Riddett-Moore, K. \& Siegesmund, R. (2012). Arts-based research: Data are constructed, not found. In S. R. Klein (Ed.), Action Research Methods (pp. 105-132). New York, NY: Palgrave MacMillan. 
Siegesmund, R. (2012). Dewey through a/r/tography. Visual Arts Research, 38(2), 99-109.

Siegesmund, R. (2017). Inquiry through art: John Dewey's "Art as experience". Unpublished manuscript, Northern Illinois University, DeKalb, IL.

Siegesmund, R. (2018). Nomadic materiality within arts-based research. European Congress of Qualitative Inquiry Proceedings 2018, 101-110.

Siegesmund, R. \& Freedman, K. (2018). Interpreting visual information in research: Tacit knowledge and nomadic inquiry. European Congress of Qualitative Inquiry Proceedings 2018, 34-40.

Springgay, S. \& Truman, S.E. (2018). Walking methodologies in a more-than-human world: WalkingLab. London, UK: Routledge.

Taylor, C.A. (2017). Rethinking the empirical in higher education: Post-qualitative inquiry as a less comfortable social science. International Journal of Research \& Method in Education, 40(3), 311-324. doi:10.1080/1743727X.2016.1256984

Tuck, E. \& McKenzie, M. (2015). Place in research: Theory, methodology and methods. New York, NY: Routledge.

Tweewaters (2012). Twist. Retrieved January, 7, 2018, from http://www.tweewaters.be/ wijk twist.php\#wijk twist

Wang, Q., Coemans, S., Siegesmund, R., \& Hannes, K. (2017). Arts-based methods in socially engaged research practice: A classification framework. Art/Research International : A Transdisciplinary Journal, 2(2), 5-39. doi:10.18432/R26G8P 


\section{ENDNOTES}

1 The transcripts of the go-along interviews with the artists are included in the analysis of the art works presented in this paper, but its detailed discussion is subject of a different paper. 